\title{
Financing Crunch on Islamic Banking And Monetary Stability In Indonesia
}

\author{
"Sugianto \\ (Department of Islamic Banking,Faculty of Islamic Economics and Business State Islamic University Sumatera \\ Utara,Medan, Indonesia) \\ Corresponding Author: sugianto@uinsu.ac.id
}

\begin{abstract}
Financing crunch is a situation where a decline in the financing supply of Islamic banking fastly as a result of a decline in the willingness of banks to channel financing to business. Financing crunch may occur as a result of the economic crisis and macroprudential policy. This study used monthly time series data from January 2007 to December 2015. Data related to the total financing extended by the Islamic banking, total funding (DPK), FDR (financing to deposit ratio) and total financing for SMEs. The research analysis which used is trend analysis in four conditions i.e. (1) the condition of the financial crisis in the United States, (2) the condition of the world economic slowdown, (3) when macroprudential policy is applied to Islamic banking; and (3) LTV and DP policies and LDR Reserve policy. This result is Islamic bank financing in crisis situation and the implementation of LTV and DP policy and LDR Reserve policy did not result in a financing crunch on Islamic banking. While the slowdown in financing the SMEs sector is caused by factors of economic conditions.
\end{abstract}

Keywords:financing crunch, macroprudential, economic crisis, SME.

Date of Submission: 05-07-2017

Date of acceptance: $22-07-2017$

\section{Introduction}

The main issues that need attention in depth related to monetary policy isnot only related to monetary stability, but also whether the process of monetary policy has a linear relationship to the real economy (Bank Indonesia, 2014b). In the context of Islamic economics, monetary sector must haverelated to the real economy.Because if the monetary sector do not have adirect impact on the real sector of the economy, the economy develop to ensured that in a ribawi circles. That is, because the financial system has an important role in the implementation of financial intermediary including to the real sector financing (Karim, 2011). If the financial system is compromised of various factors such astheglobal financial crisis, it will havean impact imposed on the financial stability of a country. Furthermore, it will affect the whole structure of the economic systemincluding aslowdown in the real sector enterprises. The next result is the collapse of the economy of a country (Mihajat, 2016). The Islamic banking and finance in Indonesia is growing rapidly after the issuance of two banking acts. First, the issuance of the new Banking Act of 1998. Since that, Indonesia has implemented a dual banking system, conventional banks and Islamic banks operate side by side in the whole of Indonesia. Second, the issuance of the new Bank Indonesia Act in 1999. According to this Act, Bank Indonesia as an Indonesia Central Bank has been given a dual mandate as the monetary authority to conduct monetary policy both conventional and Islamic. In 2000, there were two Islamic banks (BUS) and three Islamic business unit (UUS) with 65 offices and only controlled $0.17 \%$ of total assets. While the end of 2015, has been established 12 Islamic banks, 22 UUS and 163 BPRS with 2,747 offices and 2,009 office channeling counters in conventional banks. Growth of Islamic banks in Indonesia can be seen from the amount of savings and expansion financing. In 2000, total deposits reached 1.03 trillion rupiah and financing reached 1.27 trillion rupiah, with FDR (financing to deposits ratio) of $123 \%$. At the end of 2015, total deposits grew 6,112\% from the previous year and reached 231.175 trillion rupiah, while financing grew $11.37 \%$ from the previous year and reached 221.996 trillion rupiah, with FDR $88.03 \%$ (for BUS and UUS) and 120, 06\% (for BPRS). If compared with 2013, the growth in deposits and especially funding has decreased. Financing growth per year in 2013 grew $75.36 \%$. (SPS Islamic Banking, BI 2000 and OJK 2015). Credit crunch and financing crunch has very important implications for monetary policy, the implications for the effectiveness of monetary policy is mainly due to the blocking of the transmission path of monetary variables to economic activity. Low desire banks to extend credit primarily triggered by factors such as adverse selection, the risk of the business world, lack of bank capital caused interest rates, profit margins or the result is not a measure used by banks to extend credit to a debtor. This paper intends to discuss issues of whether the economy is less promising (such as the onset of the crisis) and macroprudential policies caused financing crunch in Islamic banking? Is such financing crunch has implications for monetary stability, mainly related to business failure?

DOI: $10.9790 / 5933-0804022532 \quad$ www.iosrjournals.org $25 \mid$ Page




\section{The Macroprudential Policy}

\section{Literatur Review}

The macroprudential policy is a major component in maintaining the stability of the financial system and part of the main policies. The macroprudential policy is defined and implemented by Bank Indonesia. The objectives of implementation of the macroprudential policy are (1) to prevent and reduce systemic risk, (2) to encourage intermediation balance for the economy, (3) to improve access and efficiency of the financial system in order to maintain the stability of the financial system, and (4) to support monetary stability and stability payment system (Sugianto, 2015).

Risk Systemic referred to above is the potential disruption of all or part of the financial system that arise because of the contagion due to the linkage (interconnectedness) between institutions and/or financial markets and the tendency of the behavior of financial institutions to follow the economic cycle, which can pose a threat to the national economy. While the Financial System Stability (or in Indonesia is Stabilitas Sistem Keuangan/SSK) is a condition in which financial institutions and financial markets function effectively and efficiently and be able to withstand internal and external vulnerability so that the allocation of funding or financing sources can contribute in supporting sustainable economic growth. (Bank Indonesia, 2014)

The term "macroprudential" generally denoted a systemic oreintation of regulation and supervision linked to the macroeconomy (see Borio, 2009). Over the past two decades and until the crisis erupted, the literature on monetary policy has seen a broad convergence of views on the policy objective (See e.g. Borio et al, 2003; Orphanides and Williams, 2010). The literature on macroprudential policy is still far from such a consensus on its objectives. Broadly speaking, macroprudential policy is seen as aiming at financial stability but there is no commonly shared definition of financial stability. An alternative view defined the goal of macroprudential policy as limiting the risk of episodes of system-wide distress that have significant macroeconomic costs (Borio and Drehmann, 2009a). A useful starting point in understanding the nature of macroprudential policy according to this view is the distinction between the macro- and the microprudential perspectives to regulation (Crockett, 2000). Differences between microprudential and macroprudential can be seen in Table 1 .

Table. 1. Macroprudential versus microprudential perspectives

\begin{tabular}{lll}
\hline \multicolumn{1}{c}{ Element } & \multicolumn{1}{c}{ Macroprudential } & \multicolumn{1}{c}{ Microprudential } \\
\hline Proximate objective limit & $\begin{array}{l}\text { limit financial system-wide distress limit } \\
\text { distress of individual institutions }\end{array}$ & limit distress of individual institutions \\
\hline Ultimate objective & $\begin{array}{l}\text { avoid macroeconomic costs linked } \\
\text { tofinancial instability }\end{array}$ & $\begin{array}{l}\text { consumer (investor/depositor) } \\
\text { protection }\end{array}$ \\
\hline Characterisation of Risk & $\begin{array}{l}\text { "endogenous" (dependent on } \\
\text { collective behavior) }\end{array}$ & $\begin{array}{l}\text { "endogenous" (dependent on } \\
\text { collective behavior) }\end{array}$ \\
\hline $\begin{array}{l}\text { Correlations andcommon } \\
\text { exposuresacross institutions }\end{array}$ & Important & Irrelevant \\
\hline Calibration of prudential controls & in terms of system-wide risk; topdown & in terms of risks of individual institutions; \\
& bottom-up \\
\hline Focus & $\begin{array}{l}\text { Systemic financial institutions (systemivally } \\
\text { important financial institution/SIFIs) }\end{array}$ & individual financial institutions \\
\hline Source: Borio $(2003)$ and Bank & Indonesia (2014)
\end{tabular}

Source: Borio (2003) and Bank Indonesia (2014)

The implementation of macroprudential policy in Indonesia are (Bank Indonesia: 2014):

1. LoantoValueRatio (LTV) for mortgage policies (KPR) and Down Payment (DP) for KKB

LTV for mortgage and DP for vihicle loans (KKB) policies conducted with the issuance of SE BI No.14/10/DPNP on15 March 2012 for a conventional bank and SEBI No.14/33/DPbSon 27 November2012 for an Islamic commercial bank. Recalibration with SE BINo.15/40/DKMP24 September 2013.

LTV and DP policy objectives are to curb systemic risk that may arise as a result of the growth of the mortgage (KPR) at the time it reaches more than $40 \%$, and the level of customer KKB failure to fulfill obligations when it reached almost $10 \%$. Growth in mortgages (KPR) that are too high may encourage an increase in the price of property assets that do not reflect actual prices (bubble), so as to increase the credit risk for banks with large exposure to property loans. Principal provisions of the rules above are progressive LTV for mortgage (KPR) and 20\% -30\% DP for KKB.

2. Statutory Reserves (GWM) based on Loan to Deposit Ratio (LDR)

This GWM policy is outlined in PBI No.12/19/PBI/2010 dated October 4, 2010, amended by PBI No. 15/7/PBI/2013 dated September 26, 2013, and SE BI No.15/41/DKMP October 1, 2013. This GWM provisions is to increase the resilience of the banking sector in the face of risk, particularly related to credit risk and liquidity. So it can support the stability of the financial system at the same time monetary stability by strengthening the role of the intermediary bank.

LDR GWM Policy (SE External No. 15/41/DKMP dated October 1, 2013). Obligations secondary GWM which is currently at $2.5 \%$ would be raised: 
2.1. To 3\% of deposits of bank in Rupiah from 1 - 31 October, 2013.

2.2. To 3.5\% of deposits of bank in Rupiah since 1 November -1 December 2013

2.3. To 4\% of deposits of bank in Rupiah since December 2, 2013.

Adjustments are made to the upper limit of the LDR GWM lowered from $100 \%$ to $92 \%$, while the lower limit remains at $78 \%$. Bankis expected to keep their LDR in the range of $78 \%$ to $92 \%$.

Disincentives upper limit imposed on banks that have LDR over 92\% in the CAR (Capital Adequacy Ratio) of less than $14 \%$, while the lower limit imposed disincentive to banks with LDR less than $78 \%$. The calculation disincentive for violation of the upper limit or lower limit is done with a calculation mechanism established by Bank Indonesia.

3. Transparency Prime Lending Rate (SBDK)

This policy is based on SE BI No.13/5/DPNP on 8 February 2011, amended by SE BI No.15/1/DPNP on15 January 2013.This policy objectives are:

3.1. Mitigating credit risk through healthy competition in the banking industry;

3.2. Improve good governance and competition through better market discipline;

3.3. Encouraging banks to create formulations lending rates efficiently and accurately;

3.4. Improve the transparency of banking products and services, particularly related to the calculation of benefits, risks and costs; and

3.5. Increase customer protection through mitigation asymmetric information between customers and banks. Prime lending rate (SBDK) provisions are:

3.1. Banks are required to report to BI and perform routine publication of components to prime lending rate component for each corporate loans, retail, consumption (mortgage and non-mortgage), and micro-credit (through changes SE in 2013).

3.2. SBDK components that must be reported is the cost of funds for credit (HPDK), overhead cost and profit margins. While the risk premium is not notifiable.

\section{Financing Crunch}

Theoreticallyfinancingcrunchhas not beenmuch discussed. But thecredit crunchithas been widelydiscussed.Therefore, this discussionstartedfromthe theory ofthe credit crunch. The termcredit crunchemergedin 1966asa form ofdisintermediationphenomenonthathappensin America whenthe monetary policyconducted bythe FederalReserveto be verytightto tackle inflation. A very strictpolicythathas increasedshort-terminterest ratesto risemuch abovethe upper limitof deposit ratesset byRegulationQ.As a result,depositors withdrewtheir funds frombanks togethigherinterest ratesonother financialassetsso thatbank depositsexperienced a greater declineresulting ininhibition ofthe supply ofcredit. Since thederegulation ofthe financialsectorinthe 1980sthatabolished thelimit ofinterest rates on deposits(Regulation Q), the phenomenon ofbankingdisintermediationdue toregulationslike this do nothappen again(Kliesen andTatom, 1992).

A broader definition is that the credit supply restrictions on non-price (non-price credit constraint) as a result of overly restrictive banking regulations such as regulatory capital issues and legal lending limit; or as a result of the decline in asset quality and profitability of banks (Bank Indonesia, 2001). In more technical terms, Bernanke and Lown (1991) defines credit crunch as a shift in the supply curve of bank loans with interest rate condition and the quality of potential customers has not changed. This definition is in line proposed by Pasarbasioglu (1996), which defines credit crunch as a decline in credit supply due to declining willingness of banks to lend, without being followed by a rise in interest rates on loans. The most strong definition given by Gosh and Gosh (1999) which defines credit crunch as quantity rationing, where the lending rate is no longer functioning in balancing demand and supply of credit. It is linked to the concept of credit rationing put forward by Stiglitz and Weiss (1981) and Jafee and Stiglitz (1990), which define credit rationing as a condition in which certain customer does not get the credit even though they are willing to pay the loan interest rate is higher.

From the variousdefinitions ofthe above, generally credit crunchcan be defined asasituation where thesupply ofbank creditdecreasedsharplyas a resultof adecline inthe willingnessof banksto extend creditto thebusiness world. Reluctance of banksin lendingwas reflected in theincreasedspreadis the differencebetweenlendinganddeposit interest rateand themore strictcriteria forobtaining credit. Inextreme conditions, the credit crunchoccurredin the formof creditrationing, the bankrefusedto give credittoa particularcustomerorthe majority ofcustomersatany given interestrate (Bank Indonesia, 2001). Credit decline may occur due to a decline in demand or supply on bank credit.

Credit decline caused by demand factors are something very natural to happen during the recession as an ongoing, mainly due to weak investment activity. At the micro level, structural problems such as the adjustments made by the company to reduce the debt-equity ratio increased due to the crisis may also be one of the factors that can explain why the demand for loans also decreased. Although the decline in demand for loans more often occur as a result of the factors weakening investment during the recession, microeconomic structural factors such as the above are not uncommon in a post-crisis economy (Bank Indonesia, 2001). 
On the supply side, the decline in credit due to the decrease willingness of banks to provide loans at prevailing interest rates. Factors that may cause a decrease in the willingness to give loans can be sourced from internal factors and external factors banks. Internal factors such as poor quality of banking assets, the high nonperforming loans and the drop in bank capital due to depreciation and negative interest margin decreases the ability of banks to lend (Bank Indonesia, 2001).

Institutionally, the closure of almost half the number of banks in Indonesia is very influential on the behavior of banks. First, the collapse of several banks to reduce the value of the liquidation of all banking institutions thus increasing the bankruptcy costs to be borne by the owner of the bank if the bank is liquidated (Shleifer and Vishny, 1992). This causes the banks that survive will be more conservative (risk averse) in business. Secondly, the closure of a number of banks by the government, which at a certain level means the government was ready to close poorly performing banks, have reduced the incentive for banks to act moral hazard through a signal that the government has changed its strategy in dealing with troubled banks. This led banks to rapidly restore the level of health for not exposed to liquidation. Because of the level of health, one of which is measured by the achievement of Capital Adequacy Ratio (CAR), the bank started to adjust its asset portfolio including reducing its credit, to maintain or increase its CAR.

Froman externalside, especiallyreduced levels ofcreditworthinessofthe debtoras a result ofthe weakening ofthe company's financialcondition. In certain situationswhen abankis difficultto distinguish credit worthiness of borrowers, the banks will reduce the volume ofcredit. Non-pricecreditrationinglike this can happenin avariety of forms: somedebtorsstill get creditwhileother debtorswiththe samelevel ofcredit worthiness may be affected by credit rationing; rationing of credits for certain sectors (eg consumer credit) or certain groups of debtor (small business); or the number of debtors who seem worthy of credit was also rejected because the bank does not have complete information about the financial data of debtors.

Whatever the cause, the decline in credit due to supply factors can be described by shifting the supply curve (Graph 2). Credit decline due to declining supply push up lending rates and tightening credit terms. However, the reluctance of banks to extend credit are often not followed by rising interest rates, but rather in the form of a reduction in the quantity of credit (non-price credit rationing). This can be understood as a result of deteriorating credit risk of the business world and because of the problem of information that banks cannot distinguish the quality of the debtor. In determining the quality of the debtor, banks need to know where the debtor both have a good financial position with a lower risk, and which bad debtors who have a bad financial position with potential high risk. This issue is exacerbated when the banks experienced a change of management with new ones. Because of the relationship between banks and credit customers are long-term, Long-term relationship reduces the problem of moral hazard (because if customers default they are difficult to get credit in the future) and the issue of information because the bank can study the behavior of its clients from time to time (Bank Indonesia, 2001). Based on the above, financing crunch can be defined as a situation where a decline inthe supply of financing Islamic banking sharply as a result of the declining willingness of banks in channeling finance to the business world.

\section{Methodology}

This study uses monthly time series data taken from Islamic Banking Statistics (SPS) Bank Indonesia and the Financial Services Authority (OJK). Data from January 2007 to December 2015. Data related to the total financing extended by the Islamic banking, total funding (DPK), FDR (financing to deposit ratio) and total financing for SMEs. The research analysis which used is trend analysis by dividing the analysis to four (4) conditions. Two first condition is when the economy is in crisis and slowdown. First, the condition of the financial crisis in the United States and second, the condition of the world economic slowdown. While the latter two conditions is when macroprudential policy is applied to Islamic banking. Two of the policy is LTV and DP policy and LDR Reserve policy. This analysis method is done by looking at the development and growth financing on those conditions. The analysis tools used are graphs.

\section{Islamic Banking Financing}

\section{Findings And Discussion}

Islamic banking financing that studied are within 4 conditions. First, the world economy in financial crisis condition in the United States. Second, the Indonesian economy in slowdown conditions characterized by weakening of the rupiah against the US dollar. Third, before and after the BI macroprudential policies are LTV and DP policies. Fourth, before and after the LDR Reserve policy.

The financial crisis that occurred in the United States in 2008 originated from the problems that arise on housing loans (subprime mortgage). The crisis in the US is impacting the world economy quickly. Although Indonesia is not directly affected by the crisis, but still influential, especially for companies and business activities are directly related to the United States and other countries those directly affected from the crisis in the United States. 
Base on these conditions the question whether the conditions of the crisis also affected the Islamic banking financing. The analyzed data is the data for 2007 - 2009 are intended to see the difference before and after the year 2008 when the crisis. The growth of total financing, total funding and financing to deposit ratio (FDR) Islamic banks can be seen in Figure 1. Based on Figure 1 can be described that financing in Islamic banks do not have much effect. The decline occurred in January 2008 by $3 \%$ and in December 2008 by $0.87 \%$. While funding also decreased in January 2008 by $1.13 \%$ and the largest in the month of March 2009 by $11.93 \%$. It can be concluded that in this crisis does not happen financing crunch.

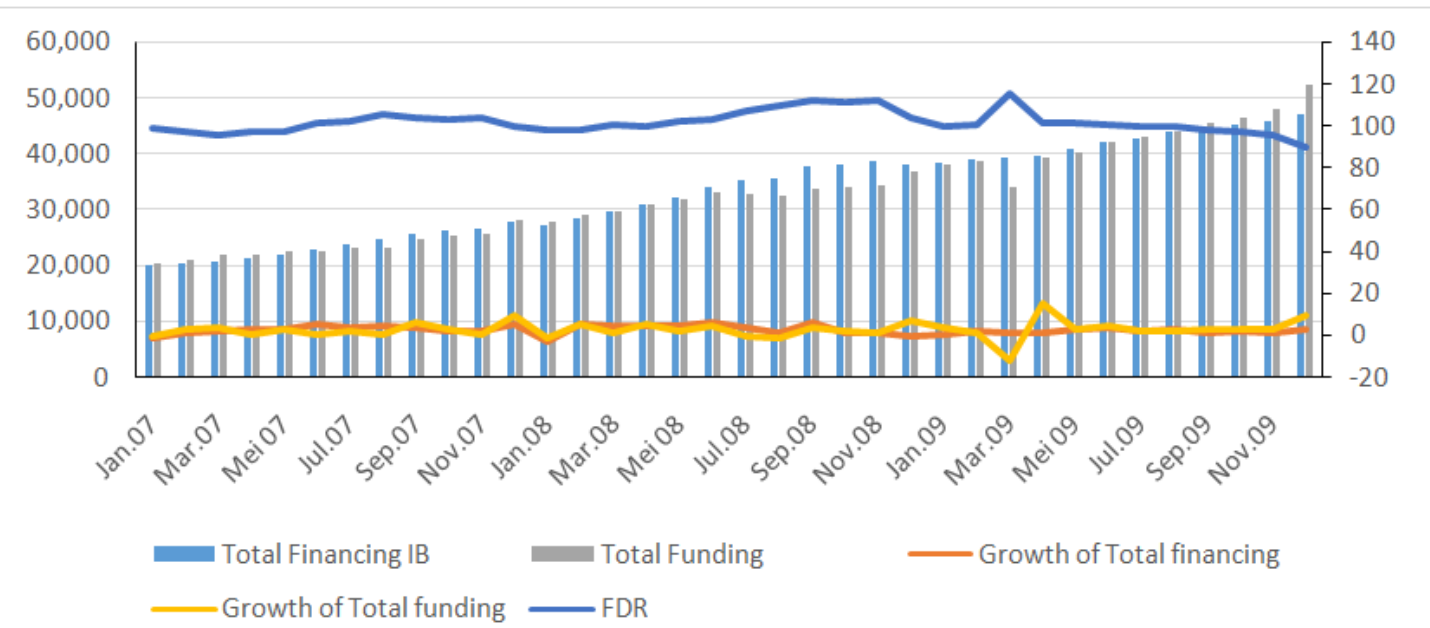

Figure 1. Growth of Financing, Funding and FDR Islamic Bank Before and After Financial Crisis in United State 2008.

The second condition, namely the Indonesian economy in slowdown conditions characterized by weakening of the rupiah against the US dollar. The analyzed data is data from January 2013 to December 2015 was intended to see growth throughout the analysis period when the world economic slowdown and Indonesia still occur. The growth of total financing, total funding and financing to deposit ratio (FDR) of Islamic banks can be seen in Figure 2.

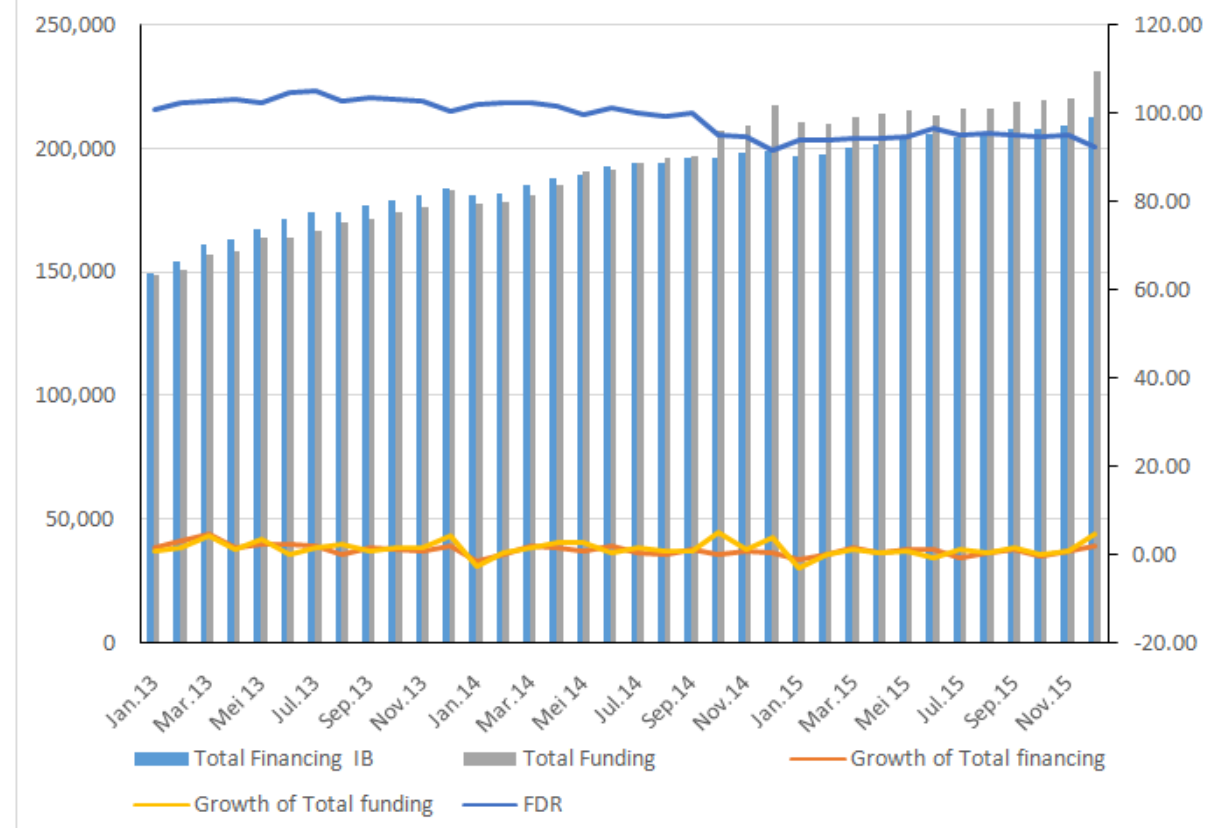

Figure 2. Growth of Financing, Funding and FDR Islamic Bank Period 2013-2015 
Based on Figure 2 can be described that financing in Islamic banks had little influence on both the world economic slowdown and Indonesia. There is fluctuating if seen from growth occurs that is not too sharp. Only in January 2014 the losses about 1.48\%. Similarly, the total funding also had a fluctuation. The decline occurred in January 2014 amounted to 3.04\% and in January 2015 by $3.46 \%$. While FDR including still high at above $90 \%$. It can be concluded that in this crisis does not happen financing crunch. The third and fourth conditions are associated with BI macroprudential policy, namely LTV and DP policy and LDR Reserve policy. Since both of these policies in the same period, the data are analyzed in the same period, ie the period November 2011 to September 2014. The growth of total financing, total funding and financing to deposit ratio (FDR) Islamic bank can be seen in Figure 3.

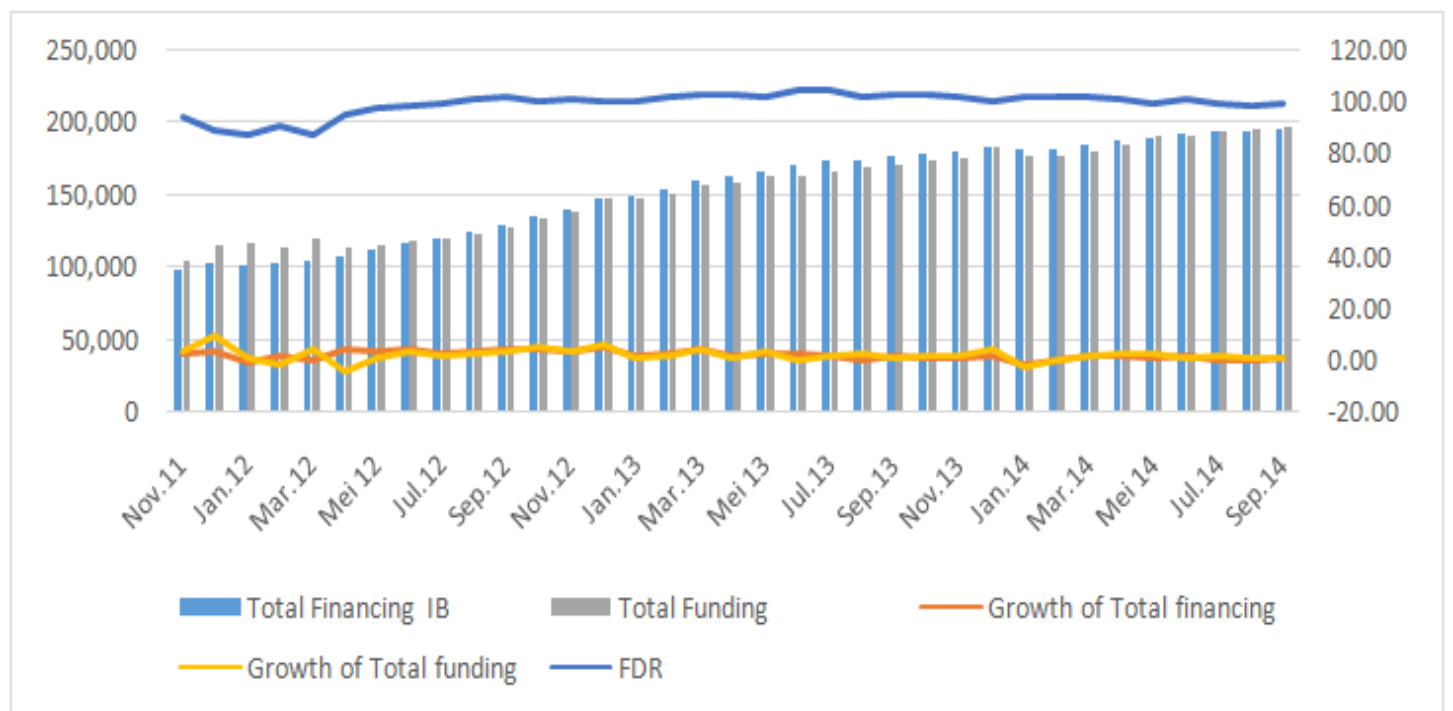

Figure 3. Growth of Financing, Funding and FDR Islamic Bank Before and After LTV, DP and GWM LDR Policy

Based on Figure 3 can be described that the overall financing in Islamic banks do not have much effect as a result of LTV and DP policy and LDR Reserve policy. If seen from growth occurs fluctuating that is not too fast, both financing, deposits and FDR. It can be concluded that in these two conditions do not occur financing crunch. Descriptive analysis of the growth of total financing of Islamic banks in Indonesia turned out to be less affected from the crisis and the slowdown of the world economy also hit Indonesia. In terms of macroprudential policy also indicates that the development of Islamic banking financing is not much affected. It can be further analyzed the characteristics of the subject of financing, as analyzed in the next section.

\section{Financing for MSMEs Business}

The second problem in this study is whether the financing crunch that occurred implications for monetary stability, mainly related to the business failures. In this study the data of the business is the total Islamic banking financing to MSMEs (micro, small and medium enterprises). The reason of this data election is the first, the Islamic economic system of the financial sector should be directly related to the real sector. This means that any funds collected should be channeled to the real sector by Islamic banks. Second, Islamic banking financing designation of the subject can be classified in two categories, namely the financing of MSMEs and non MSMEs. Thirdly, the largest total financing is intended to MSMEs. Fourth, the business development of the business world can also be known from the amount of financing in Islamic banks. Analysis of financing for MSMEs is also based on four conditions. First, the world economy in financial crisis condition in the United States. Second, the Indonesian economy in slowdown conditions characterized by weakening of the rupiah against the US dollar. Third, before and after the BI macroprudential policies are LTV and DP policies. Fourth, before and after the LDR Reserve policy.

Based on the first condition, the question is whether the conditions of the crisis also affected the Islamic banking financing. The analyzed data is the data for 2007 - 2009 are intended to see the difference before and after the year 2008 when the crisis. The growth of total financing and financing for MSMEs Islamic banks can be seen in Figure 4. 


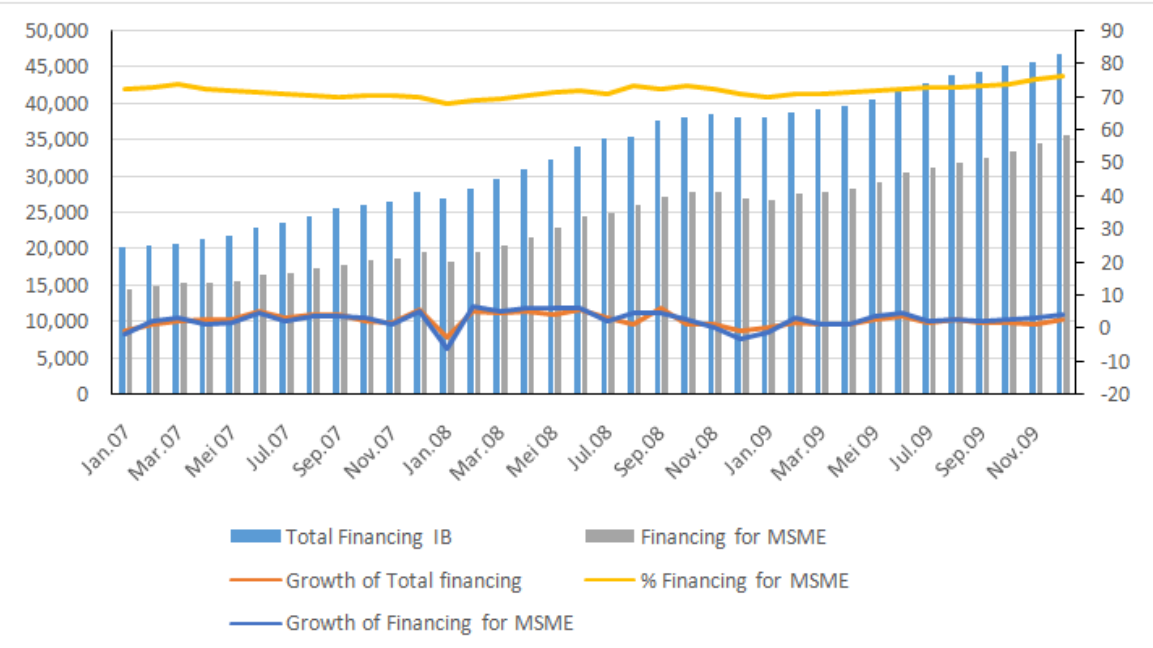

Figure4. Growth of Total Financing and Financing for MSME Islamic Bank Before and After Financial Crisis of United State 2008

Data shown by Figure 4 illustrates the MSME business decreased when seen from the description of the MSME financing, amounting to $6.08 \%$ in January 2008. This is in line with the decrease in total financing extended by the Islamic banking in the same period amounted to $3.00 \%$. However, financing of MSMEs is still larger than any non MSME financing, about $67.81 \%$. But overall, a rather large decrease only occurred in the month of January 2008, the rest fluctuations are not too large. If further analyzed the percentage of financing of MSMEs is on average over 70\%. This shows that MSMEs are not too affected by the crisis. This sector has a resistance effort. So if Islamic banks more provide financing disbursement to the sector are likely to be able to survive well. MSME business conditions in the state of the Indonesian economy slowing conditions characterized by weakening of the rupiah against the US dollar is shown by the data of the period January 2013 to December 2015. The growth of total financing and MSME financing can be seen in Figure 5.

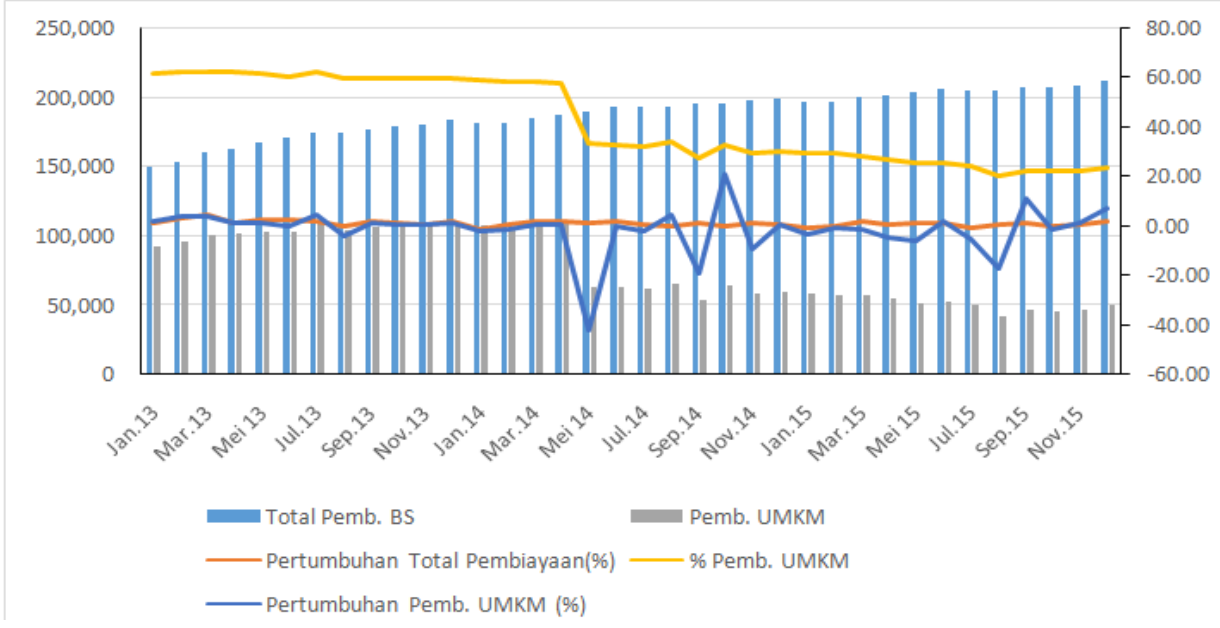

Figure 5. Growth of Total Financing and MSME Financing from Islamic Bank Period 2013-2015

Based on the data shown by Figure 5 can be described some things. First, total financing in general suffered only minor fluctuation and had no major shocks. Second, the other side MSME financing occure a significant decrease since May 2014. Since this period the portion of MSME financing under $34 \%$ that previously were above 50\%. It showed a slowdown in growth of business in the MSME sector. Third, two of the above with a significant decrease in the MSMEs financing are not directly related to the decrease in total Islamic bank financing. The third and fourth conditions are related with BI macroprudential policy, ie. LTV and DP policy and LDR Reserve policy. As the first problem analysis, in the analysis of this data is also analyzed in the same period, ie the period November 2011 to September 2014. LTV and DP Policy are in the period November 2012 to September 2013, whereas the LDR Reserve policy is the period of October 2013. Growth in total financing and total financing of MSMEs in islamic banks can be seen in Figure 6. 


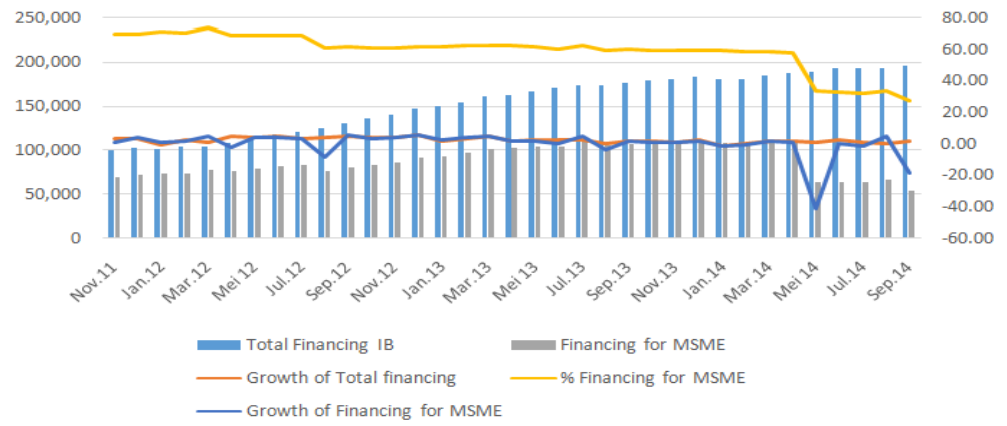

Figure 6. Growth of Total Financing and Financing for MSME Islamic Bank Before and After LTV, DP and GWM LDR Policy

Figure 6 shows some of the following. First, the LTV and DP policy had no effect on either total Islamic bank financing and MSMEs financing. This is because the LTV and DP policy destined for consumer financing, ie KPRS financing and ownership of motor vehicles. Second, LDR Reserve policy also does not have much effect on the total financing and MSME financing. Descriptive analysis of the growth of MSME financing shows that the decline in MSMEs financing is not always due to a decrease in total Islamic bank financing. This only happens in the period January 2008 by $6.08 \%$ with a decrease of $3.00 \%$ in total financing. The decline in MSME financing more due to the conditions of the world economic slowdown also hit Indonesia.

\section{Conclusion}

Macroprudential policy is applied in order to secure financial stability. While financing crunch clearly gives disturbance to monetary policy even further consequences are resulted in a decline in investment in the real sector. Furthermore, we will slow down the economic turnaround. So the financing crunch should be prevented by macroprudential policy. Descriptive analysis in this paper show that has not happened financing crunch in the Islamic banking. Although the finance portfolio at a certain period occure a volatile but has yet to show a fast slowdown. The analysis also showed that the distribution of funding to MSMEs as a special feature of Islamic banks with an average above 55\% of total Islamic bank financing demonstrates the strength of the sector. So that Islamic banks should be serious attention to this sector, not only giving but strengthening the financing and mentoring. Study and research on financing crunch need further attention. Because the characteristics of Islamic bank financing different from conventional banks, the deeper study is needed.

\section{Refference}

[1] Agung, J. (1998). Financial Deregulation and Bank lending channel in Developing Countries: The case of Indonesia. Asian Economic Journal, Sep., 12(3), pp. 273-294.

[2] Agung, J. (2000). Financial Constraints, Firms' Investment and the Channel of Monetary Policy in Indonesia. Applied Economics.

[3] Bagian SPPK - DKM. (2000). Struktur Pembentukan Suku Bunga Dari Sisi Perbankan Untuk Menunjang Efektivitas Kebijakan Moneter, September 2000

[4] Bank Indonesia. (2014a). FGD Kebijakan Makroprudensial dan Stabilitas Sistem Keuangan.

[5] Bank Indonesia. (2014b). Credit Crunch di Indonesia Setelah Krisis Fakta, Penyebab dan Implikasi Kebijakan.

[6] Bernanke, B. and Lown, C. (1991). The credit crunch. Brooking Paper in Economic Activity. February.

[7] Bernanke, B., Gertler, M. and Gilchrist, S. (1996). The Financial Accelerator and the Flight to Quality. Review of Economics and Statistics. Feb 1996:1-15.

[8] Ding, W., Domac, I, and Ferri, G. (1998). Is there a Credit Crunch in East Asia? World Bank - Policy Research Working Paper Series No.1959.

[9] Domac, I, and Ferri, G. (1998). The Real Impact of Financial Shocks: Evidence from the Republic of Korea. World Bank - Policy Research Working Paper Series, No.2010.

[10] Gosh, A. and Gosh, S. (1998). East Asia in the Aftermath: Was there a crunch?. IMF Working Paper 1999/38.

[11] Karim, Adiwarman A. (2011). Bank Islam: Analisis Fiqh dan Keuangan. Jakarta: PT RajaGrafindo Persada.

[12] Kim, H.E. (1999). Was Credit Channel a Key Monetary Transmission Mechanism following the Recent Financial Crisis in the Republic of Korea? World Bank - Policy Research Working Paper Series No.3003.

[13] Kliesen, K.L. and Tatom, J.A. (1992). The Recent Credit Crunch: The Neglected Dimensions. Federal Reserve Bank of St Louis Economic Review. September/ October 1992.

[14] Mihajat, Muhammad Imam Sastra. (2016). Macro-prudential Supervision in the Indonesia Financial Services Authority (OJK) and the Role of Sharia Board: A Proposal Framework. Journal of Islamic Banking \& Finance: Global Perspective on Islamic Finance. Oct-Dec: $72-85$.

[15] Pazarbasioglu, C. (1997). A Credit Crunch? Finland in the Aftermath of the Banking Crisis. IMF Staff Paper. Vol. 44: 315-27.

[16] Stiglitz, J.E. and Weiss, A. (1981). Credit Rationing in Markets with Imperfect Information. The American Economic Review. Jun: $393-410$.

[17] Sugianto. (2015). The Financing CrunchAnd The Macroprudential In Indonesia. Paper Conference in Cairo, Egypt.

Sugianto. "Financing Crunch on Islamic Banking And Monetary Stability In Indonesia." IOSR Journal of Economics and Finance (IOSR-JEF) 8.4 (2017): 25-32. 